\title{
Prisotnost vsebin o nasilju v šoli v kurikulih pedagoških fakultet
}

\author{
Veronika Tašner in Sanja Berčnik
}

$\mathrm{N}$

asilje v šoli ostaja pereč problem, tako na nacionalni kakor tudi na globalni ravni. Ko mediji poročajo o ekscesnih primerih nasilja v šoli, posebej o medvrstniškem nasilju, se hitro postavi vprašanje, kaj je storila šola, da bi tovrstne primere nasilja preprečila. Najpogostejši odgovor je: premalo. Omenjenemu vprašanju sledi vprašanje o kompetencah in usposobljenosti učiteljstva za spoprijem z nasiljem $\mathrm{v}$ šoli in družini, včasih tudi o sistemskih zagatah pri reševanju omenjene problematike. Primer tovrstne obravnave se je zgodil leta 2015 , ko je bila I2. junija sklicana seja Odbora za izobraževanje, znanost, šport in mladino $v$ Državnem zboru $R S$. Na omenjeno sejo so bili k prvi točki dnevnega reda (Medvrstniško nasilje v šolah) vabljeni posamezniki in posameznice, ki se tako ali drugače ukvarjajo s problematiko nasilja in šole. Povod za sklic so bili medijsko odmevni primeri nasilja na različnih osnovnih šolah po Sloveniji v letu 20I4. Cilji sklica pa vsaj vnaprej niso bili najbolj jasno artikulirani. Predsednica odbora je zato na začetku pojasnila, da je želja sklicateljev seje »identificirati slabosti ureditve vseh pojavnih oblik medvrstniškega nasilja«. V razpravi pa je bilo v nadaljevanju mogoče zaznati predvsem precejšnje nezadovoljstvo z reševanjem nasilja v šolskem kontekstu. Razprava je hkrati ponovno potrdila dejstvo, da govor o nasilju in šoli prepogosto spremlja spregled kompleksnosti omenjene problematike, ki je močno odvisna od družbenega konteksta, od nacionalnih politik in praks ter splošne družbene naravnanosti do nasilja kot takega, na kar so nekateri razpravljalci in razpravljalke sicer poskušali opozoriti. Zelo hitro se diskusije sklenejo z ugotovitvami, da bi morale šole storiti bistveno več pri preprečevanju nasilja, da imajo pri tem težave zaradi neustreznih 
predpisov, ki včasih celo zavirajo ustrezno ravnanje učiteljstva, in da je slednje bolj ali manj na sploh neusposobljeno za reševanje tovrstne problematike ipd. Večina hkrati terja še rešitve tukaj in zdaj (povzeto iz diskusije na odboru 12. junija 2015).

Prepogosto je spregledano dejstvo, da šola kot vzgojno izobraževalna institucija, sama in v celoti, ne more uspešno opraviti z nasiljem v šoli. Čeprav, kot je mogoče zaključiti iz različnih raziskav, obstaja vrsta učinkovitih načinov spoprijema z omenjeno problematiko (glej Olweus, 1993; Green, 2005), se je treba pri tem zavedati, da je za uspešen spoprijem z nasiljem v šoli potrebno sodelovanje vseh akterjev, ne samo šole (BučarRučman, 2009). Najuspešnejši pri tem so t. i. multiagencijski pristopi, v katerih sodelujejo zaposleni na šolah, učenke in učenci, starši, lokalno okolje, nacionalna zakonodaja, mediji, policija, nevladne organizacije itd.

Nakazali sva že, da je problem nasilja širši problem družbe, a se bova za potrebe tega prispevka omejili na akterje in akterke šolskega polja in pravne akte, ki urejajo omenjeno polje. Kot sva zapisali, lahko šole skupaj $\mathrm{z}$ učiteljstvom, drugimi zaposlenimi na šoli, učenci in učenkami ter s starši okrepijo ali uspešno omejijo prisotnost nasilja. Uspešnost spoprijema je odvisna od različnih dejavnikov, ki igrajo pri pojavnosti nasilja pomembno vlogo in jih v osnovi delimo na sistemske in individualne. Pri tem je eden pomembnejših dejavnikov uspešnega spoprijema $\mathrm{z}$ nasiljem zagotovo odnos učiteljstva do nasilja. $V$ isti liniji so zelo pomembne tudi njihove kompetence, potrebne za prepoznavanje in preprečevanje predvsem medvrstniškega nasilja. V nadaljevanju prispevka se bova omejili na tematiziranje medvrstniškega nasilja, posebej v luči kompetenc prihodnjega učiteljstva, ki jih na omenjenem področju pridobijo v času študija, in na pravni okvir, ki učiteljstvu nalaga in omogoča posredovanje pri pojavih omenjene oblike nasilja.

\section{Pravne podlage za spoprijem $\mathrm{z}$ medverstniškim nasiljem}

Najprej nekaj pojasnil glede fenomena, ki ga jemljeva pod drobnogled. Medvrstniško nasilje je ena od najbolj vztrajnih in hkratih perečih pojavnosti nasilja v šoli, tako v Sloveniji kot tudi v drugih državah. Je tudi ena od bolj poznanih in najbolj raziskanih oblik nasilja. Termin, ki je za vrstniške zlorabe najpogosteje uporabljen v anglosaški literaturi, je bullying. $\mathrm{V}$ slovenščini povsem ustreznega izraza nimamo, najpogosteje pa ga prevajamo z izrazom trpinčenje, tudi tiraniziranje ali medvrstniško nasilje. Pri uporabi termina trpinčenje so vsebina, teža in stopnja nasilnega dejanja bolj jasne, medvrstniško nasilje pa izraža, da gre za nasilje med vrstniki, brez pojasnila o obliki ali stopnji nasilnosti. S trpinčenjem tako označujemo »silo ali nasilje, ki je uporabljeno z namenom ustrahovati in 
nadlegovati druge« (Besag, 1989: 2), pri čemer je pomembno opozoriti še na neravnotežje med žrtvijo in povzročiteljem (Lines, 2008). Rigby (2008) ga tako opredeli kot zlorabo moči v medosebnih odnosih in sam fokus postavlja na zlorabo moči in ne na trajanje, število subjektov, profil žrtve ali oblike nasilja. Pri tem pa velja še izpostaviti, da delimo trpinčenje na neposredno in posredno (Safran, 2007: 49).

Neposredno vključuje odprt napad na žrtev v obliki fizičnega, verbalnega nasilja in spolnih zlorab ... Posredno nasilje vključuje socialno osamitev, izključitev iz skupine ali neizbranost pri različnih skupinskih aktivnostih (ibid.).

Zelo verjetno je, da se bo učitelj ali učiteljica med svojo delovno dobo vsaj kdaj srečal/-a z vsaj eno obliko medvrstniškega nasilja v šoli. Zato je nujno, da pozna pravne podlage, $\mathrm{ki} \mathrm{mu/ji} \mathrm{nalagajo} \mathrm{in} \mathrm{omogočajo} \mathrm{ustrezno}$ ukrepanje ob pojavih omenjenega nasilja. Očitno je, da se je v zadnjih desetletjih občutljivost za človekove pravice močno povečala tudi v Sloveniji in da se je tako popravil tudi položaj posameznih socialnih in družbenih skupin. Nasilje, predvsem odkrito, v medosebnih in medskupinskih odnosih postaja vse bolj nelegitimno in razumljeno kot kratenje temeljne človekove pravice in poseg $\mathrm{v}$ osebno dostojanstvo. $\mathrm{K}$ temu so občutno prispevala družbena gibanja, tista za zaščito človekovih pravic in tudi feministična gibanja. Kot je zapisala bivša varuhinja človekovih pravic Vlasta Nussdorfer (20I4), je Slovenija za zaščito otrok, kot del obveznosti po Konvenciji o otrokovih pravicah (KOP), razvila sicer dobre sisteme socialnega, pravnega in sodnega varstva, torej celovit sistem zaščite otrok, pri čemer pa so še vedno ugotovljene »nepravilnosti in neučinkovitosti pri delovanju lokalnih ali osrednjih državnih oblasti «, predvsem v zvezi z neinterdisciplinarnim reševanjem težav, še zlasti pa so »nesprejemljive trditve nekaterih institucij, da niso odgovorne za nerešena vprašanja ali dileme zaščite otrokovih pravic«. Varuhinja je opozarjala, da gre prepogosto za prelaganje odgovornosti in ne za zavzemanje za usodo prav vsakega otroka v stiski. KOP je otrokom podelila dodatne pravice, ki jih zaradi svoje starosti niso bili deležni v Splošni deklaraciji človekovih pravic. Kodelja (1995) opozori, da so otroci človeška bitja s posebnimi lastnostmi. Omenjeni dokument jim je tako prinesel posebne pravice, kot so: pravica do vzdrževanja in zaščite, pravica do izobraževanja, ki je, zanimivo, nimajo pravice zavreči, nimajo pravice delati za zaslužek itd. Otroci kot bitja s svojstvenimi potrebami so pridobili posebne pravice, ki pa so $\mathrm{v}$ očeh nekaterih avtorjev bolj pravice in dolžnosti staršev, torej odraslih. Zato, ker otrok še ni odrasla oseba, se ga obravnava kot različnega od odraslega človeka, kot nekoga, ki - kot piše v preambuli Konvencije - »zaradi telesne 
in duševne nezrelosti potrebuje posebno varstvo in skrb « (KOP, 1990). S to pravico otroka do posebnega varstva in skrbi je povezana obveznost $\mathrm{dr}$ žave in dolžnost staršev (ali zakonitih skrbnikov), da zagotovijo uresničevanje te pravice (Archard, 2004).

Nadalje je za omenjeno problematiko pomembno poznavanje i8. člena Ustave RS (199I), v katerem piše, da nihče ne sme biti podvržen mučenju, nečloveškemu ali ponižujočemu kaznovanju ali ravnanju, kar pomeni, da je treba spoštovati tudi dostojanstvo vsakega otroka in izkazovati spoštovanje do njegove osebnostne integritete. Za uresničevanje slednjega mora učitelj/-ica $\mathrm{v}$ prvi vrsti poznati in upoštevati hišni red šole, ki nalaga ukrepe za zagotavljanje varnosti in vzdrževanje reda (ZOsn, 1996, 2006, 3r.a člen), hkrati pa mora delovati v skladu z vzgojnim načrtom šole (prav tam, 6o. člen), ki mora vsebovati proaktivne in preventivne dejavnosti, svetovanje, usmerjanje ter druge dejavnosti (pohvale, priznanja, nagrade, vrste vzgojnih ukrepov in podobno), $s$ katerimi šola razvija varno in spodbudno okolje (prav tam, 6o.d člen). Pri kršitvah pravil mora ravno tako ukrepati v skladu z vzgojnim načrtom, pri tem pa ne sme omejevati pravic učencev (prav tam, 60.e člen). Človekove in otrokove pravice so tako postale tudi vrednotni in konceptualni temelj sodobne edukacije, dolžnost le-te pa je med drugim tudi skrb za poln razvoj človekove osebnosti. Pri tem so pomembni trije koncepti: varovanje in zaščita otrok, oskrba in krepitev moči ter soudeležba (Devjak in Zorc Maver, 20I8). Šolsko okolje, v katerem se učenci počutijo varne in sprejete, oblikujejo proaktivne vzgojne dejavnosti, ki temeljijo na kakovostnem organiziranju učenja, vzajemnem spoštovanju, odgovornosti in visokih pričakovanjih na področju učenja in medsebojnih odnosov. Pri načrtovanju in izvajanju le-teh je šola avtonomna, oblikovati pa jih mora v skladu s cilji izobraževanja, zapisanimi v 2. členu Zakona o osnovni šoli (1996, 2006), v katerem je izpostavljeno vzgajanje za medsebojno strpnost, spoštovanje drugačnosti in sodelovanje $z$ drugimi, spoštovanje človekovih pravic in temeljnih svoboščin in $s$ tem razvijanje sposobnosti za življenje $v$ demokratični družbi. Organi in organizacije so tako dolžni izvesti vse postopke in ukrepe, ki so potrebni za zaščito žrtve glede na stopnjo njene ogroženosti in zaščito njenih koristi, in pri tem zagotoviti spoštovanje integritete žrtve. Če je žrtev nasilja otrok, imajo koristi in pravice otroka prednost pred koristmi in pravicami drugih udeleženk oziroma udeležencev postopka (ZPND, 2008, 5. člen). Vsakdo, zlasti pa strokovni delavci oziroma delavke v zdravstvu ter osebje vzgojno-varstvenih, vzgojno-izobraževalnih zavodov in socialnih zavodov ter izvajalci vsebin za otroke $\mathrm{v}$ športnih in kulturnih združenjih, ne glede na določbe o varovanju poklicne skrivnosti takoj obvestijo center za socialno delo, policijo ali državno tožilstvo, kadar sumijo, da je žrtev nasilja 
otrok ali oseba, ki zaradi osebnih okoliščin ni sposobna skrbeti zase (prav tam, 6. člen). Kot podrobneje nalaga Pravilnik o obravnavi nasilja v družini za vzgojno-izobraževalne zavode ( 2008 , 3. člen), mora učitelj ali drug delavec v vzgoji in izobraževanju, ki je pri otroku opazil spremembe, ki bi lahko bile posledice nasilja, ali mu je otrok zaupal, da je žrtev nasilja, ali ima učitelj ali drug delavec VIZ informacijo o nasilju od tretje osebe ali pa je bil sam priča nasilja, takoj obvestiti o tem svetovalnega delavca VIZ ali v njegovi odsotnosti ravnatelja ali pomočnika ravnatelja. Sam ali v sodelovanju s svetovalnim delavcem VIZ v primeru poškodbe pri fizičnem ali spolnem nasilju ali hudi psihični stiski otroka zaradi nasilja $\mathrm{v}$ družini tudi obvesti pristojni center za socialno delo (v nadaljnjem besedilu: CSD), izven poslovnega časa CSD njegovo interventno službo ali, če meni, da je to primerno, policijo; če so navedene posledice opažene pri polnoletnem udeležencu izobraževanja po javno veljavnih programih, zaposlena oseba udeleženki, udeležencu svetuje, naj obišče zdravnika, ter osebo seznani z možnostmi ustrezne pomoči in z organi, ki ji lahko nudijo ustrezno pomoč. Sam ali s svetovalnim delavcem naredi zapis dogodka, opažanj, pridobljenih informacij ali pogovora $\mathrm{z}$ otrokom. $\mathrm{V}$ podrobni analizi kazenskega prava Korošec (2009: 407) ugotavlja, da učitelj »potencialno kazensko odgovarja za lastna malomarna ali naklepna aktivna ravnanja z elementi nasilja, kot tudi za malomarno ali naklepno pasivnost ob ravnanjih z elementi nasilja s strani drugih oseb «. Avtor slednje utemeljuje z dejstvom, da učiteljstvo šteje za strokovno osebje, ki skrbi tudi »za dejansko varstvo interesov in pravic mladoletnih oseb, ki so mu zaupane $\mathrm{v}$ varstvo, vzgojo in učenje $\ll$ (prav tam).

Podrobnejše analize, po navedbah Smernic za analizo, preprečevanje in obravnavo/obvladovanje nasilja v šolskem prostoru (2004), kažejo, da nasilje v šoli ni nov pojav. Je pa danes družba bolj občutljiva in osveščena o nasilju, ga bolj problematizira (včasih zgolj discipliniranje, danes bolj vzgojni ukrepi in iskanje razlogov), je bolj občutljiva za razvojne zakonitosti otrok (socialna kognicija, empatija) ter poudarja človekove in otrokove pravice in odgovornosti odraslih za njihovo uresničevanje. V Sloveniji smo, sodeč po Smernicah (2004), naravnani v sistematično in strokovno ukvarjanje s problemom nasilja. Predlagana so nekatera ključna načela spoprijemanja z nasiljem, določen pa je tudi nabor ukrepov. Tako je $\mathrm{v}$ njih zapisano, da je treba v kurikularne elemente vgraditi vsebine in kompetence, pomembne za življenje v skupnosti, in skrbeti za njihovo izvajanje; graditi na pozitivni socialni klimi na šoli; poskrbeti za kakovostno preživljanje časa v šoli; nujno je tudi odzivno delovanje šole na vseh ravneh; vključenost $\mathrm{v}$ življenje na šoli; načrtovanje prostora $\mathrm{v}$ in ob šoli; skrb in odgovornost za uresničevanje varnega šolskega prostora in odzivanje na 
pojave nasilja; strokovno izpopolnjevanje zaposlenih na šoli; sodelovanje z lokalnimi organi in nevladnimi organizacijami; vključevanje staršev v življenje in delo šole ter vključevanje medijev in različnih gradiv za učitelje, učence, dijake in starše. Prav tako so predlagani ukrepi za razvijanje različnih metod in oblik poučevanja; povečanje odgovornosti za varno šolsko okolje; spremljanje izvajanja kurikularnih dokumentov (realizacija ciljev in dejavnosti), iskanje nove oblike individualne ali skupinske pomoči za učence, ki pogosto motijo pouk; izpostavljeno je dopolnjevanje in dograjevanje Pravilnika o pravicah in dolžnostih učencev; razvijanje koncepta učitelj-svetovalec (individualna komunikacija) ter dodatnih možnostih vzpostavljanja učiteljeve avtoritete; poudarjen je pomen povečane socialne vključenosti učencev; omogočanje stalne evalvacije na področju analize in preprečavanja nasilja $\mathrm{v}$ šolah; kot eno ključnih je zapisano vključevanje staršev, učencev (otroški parlament) v upravljanje s problematiko nasilja in dodano opozorilo o pomenu zagotavljanja kakovostne ponudbe programov za usposabljanje učiteljev ter razvoju sodelovanja z raznimi institucijami in nevladnimi orgnizacijami. Pred 15 -imi leti je bila predlagana ustanovitev posebnega sveta na državni ravni - v njem naj bi sodelovali ravnatelji, učitelji, učenci, starši in strokovnjaki, osnovni namen pa bi bil uveljavljati in vzdrževati določene, za konkretno šolo utemeljene koncepte in modele preprečevanja ter obravnavanja nasilja. Izpostavljena je bila tudi potreba po finančni podpori s strani Ministrstva za šolstvo za razvojno-raziskovalno delo na področju nasilja (prav tam). Smernice sicer nudijo dobro splošno osnovo za spoprijem $\mathrm{z}$ nasiljem $\mathrm{v}$ šolah in za preventivno delovanje, vendar je treba po najinem mnenju po is-ih letih od njihovega oblikovanja razmisliti o bolj zavezujočem dokumentu politike boja proti nasilju v šolah. V Smernicah gre namreč za predloge in usmeritve, vprašanje pa je, koliko je šol, ki dejansko predloge in usmeritve tudi uveljavljao v praksi. Slovenija se je namreč v primeru Smernic problematike nasilja lotila zelo široko. Zajeta so skoraj vsa načela in ukrepi, ki jih je mogoče zaslediti $\mathrm{v}$ mednarodnem prostoru, niso pa zapisana prioritetna področja. Meniva, da bi moral biti koncept boja proti nasilju v šoli vključen $v$ t. i. formalni (predpisani) okvir vzgojnega delovanja $\mathrm{v}$ javnih šolah. Ta bi obsegal zahtevo najprej po natančnem ugotavljanju prisotnosti nasilja na posamezni šoli (s pomočjo s strani strokovnjakov oblikovanih instrumentov).

Kot je zapisal Olweus (1993), je temeljna demokratična pravica otro$\mathrm{ka}$, da se počuti $\mathrm{v}$ šoli varnega, da so mu prihranjeni zatiranje in ponavljajoča se, namerna ponižanja, ki so sestavni del medvrstniškega nasilja. $\mathrm{Z}$ namenom, da zaposlenim $\mathrm{v}$ vzgojno-izobraževalnih zavodih pomagajo bolje razumeti pojav nasilja med vrstniki ter se ustrezno in učinkovito odzivati oziroma ukrepati ob zaznavi medvrstniškega nasilja, so bila $s$ 
strani Zavoda RS za šolstvo oblikovana navodila s priročnikom za obravnavo medvrstniškega nasilja v vzgojno-izobraževalnih zavodih. Navodila še vedno niso obvezujoči pravni akt, ampak ponovno podajajo smernice, usklajene $\mathrm{z}$ nacionalnimi zakonskimi in podzakonskimi akti vzgoje in izobraževanja na vrtčevski, osnovnošolski ter srednješolski stopnji. Izhajajo iz dejstva, da se vsaka vzgojno-izobraževalna institucija »sooča z različnimi oblikami nasilja, da se je na nasilje dolžna odzvati, da pa zaposlenim manjkajo strokovne usmeritve na zelo konkretni ravni« (Protokol, 20ı6: 3). Protokol predvideva, da naj bi vsaka vzgojno-izobraževalna institucija oblikovala lastno strategijo preprečevanja in obravnave nasilja, vanjo pa naj bi smiselno umestila omenjena navodila oz. protokol. Protokol poleg navodila za ravnanje vsebuje tudi priročnik, ki natančneje definira medvrstniško nasilje, dinamiko le-tega ter tudi načela obravnave medvrstniškega nasilja. Preden se bodo šolske strokovne in upravne službe odločile za naslednje korake reguliranja tematizirane problematike, bi kazalo premisliti, do kakšne mere in s katerimi akti kaže regulirati področje in kako se ogniti nevarnosti pretirane normiranosti, ki posledično pogosto rezultira v »papirni uspešnosti«. Pri tem bi kazalo ponovno premisliti razmerje med pričakovanji, ki jih kot družba usmerjamo v šolo in učiteljstvo, in tistim, kar lahko in smo celo dolžni za zmanjšanje medvrstniškega nasilja postoriti v družinah in v družbi. Šele premišljeno in uravnoteženo pričakovanje, usmerjeno v obe smeri, lahko, skupaj s formiranjem mlade generacije tako doma kot $\mathrm{v}$ institucijah formalne vzgoje in izobraževanja, prinese pomembno zmanjšanje nasilja, in tako poveča kakovost odraščanja.

\section{Kompetence učiteljstva}

Ob ustreznih predpisih, ki spodbujajo in omogočajo primerno ravnanje učiteljstva ob pojavih nasilja, je za uspeh na tem področju treba tudi ustrezno usposobljenega učiteljstva. Ob splošnih (generičnih) kompetencah so tu še splošne (generične) kompetence za strokovnjake v vzgoji in izobraževanju ter predmetno-specifične kompetence. V zadnjih desetih letih se na omenjenem ozadju izpostavljajo tudi socialno-državljanske kompetence. Pregled naštetega pokaže, da imamo opravka z zahtevnim in odgovornim poklicem, ki terja številne sposobnosti, znanja in veščine. Učiteljstvo igra ključno vlogo pri učenju otrok in mladostnikov. V vrtcih in šolah se prepletata vzgoja in izobraževanje. To poteka preko vsebin, ki jih podajajo učiteljice, vzgojiteljice, preko načina posredovanja ter tudi z lastnim zgledom - s svojimi ravnanji. Za tako zahteven poklic so ključnega pomena pogoji začetnega in vseživljenjskega izobraževanja. Brez dobrih pogojev »učiteljstvo« ne more biti usposobljeno za kakovostno opravljanje 
poklica. Ali kot zapišejo avtorji in avtorice Skupnih evropskih načel za kompetence in kvalifikacije učiteljev:

Njihov poklic, ki ga navdihujejo vrednote vključevanja in potreba po razvijanju potencialov učencev, ima velik vpliv na družbo in igra ključno vlogo pri napredovanju človeškega potenciala in oblikovanju prihodnjih generacij.

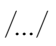

Učitelji bi se morali biti sposobni odzivati na nastajajoče izzive družbe znanja, v njej dejavno sodelovati in pripraviti učence na to, da bodo samostojni vseživljenjski učenci. Zato bi morali biti sposobni vplivati na proces učenja in poučevanja s stalnim angažiranjem na področju poznavanja predmeta, vsebine kurikula, pedagogike, novosti, raziskav ter socialnih in kulturnih razsežnosti izobraževanja. Izobraževanje učiteljev mora biti na visoki izobraževalni ravni ali temu enakovredni ravni in ga mora podpirati tesno partnerstvo med visokošolskimi zavodi in zavodi, kjer se bodo učitelji zaposlili. (ibid.)

Hkrati pa že omenjena načela opozarjajo na nekaj, kar radi preslišimo v Sloveniji, namreč, da kljub temu da »imajo učitelji v družbi zelo pomembno vlogo «, dela, ki smo ga dolžni opraviti drugi, »ne morejo opraviti sami. Njihovo visoko kakovostno izobrazbo morajo podpirati zavodi, kjer so zaposleni, v okviru doslednih nacionalnih ali regionalnih politik, za katere so zagotovljena ustrezna sredstva. Te politike morajo obravnavati začetno izobraževanje učiteljev in stalni poklicni razvoj ...«S tem pridemo še do ene točke, ki zahteva skrb družbe: »Tisti, ki usposabljajo učitelje, vplivajo na kakovost učenja in jih je zato treba podpirati kot del nacionalnega ali regionalnega sistema.«

$\mathrm{V}$ nadaljevanju se osredinjava na specifične kompetence učiteljstva, ki so samo del kompetenc, ki naj bi jih posedovalo učiteljstvo. Zanimalo naju je, ali so prihodnji učitelji in učiteljice neustrezno usposobljeni, ko gre za vprašanje nasilja $\mathrm{v}$ povezavi s šolo ter poznavanje pravnih dokumentov, saj je to eden glasnejših očitkov javnosti, ko pride do ekscesnih primerov nasilja v šoli (glej sejo Odbora ..., I2. junij 2015).

\section{Vsebinski pregled kurikulov na slovenskih pedagoških fakultetah $^{\mathrm{I}}$}

Da bi ugotovili, kako je s pokritostjo vsebin nasilja in šole v kurikulih pedagoških fakultet, sva pod drobnogled vzeli učne načrte predmetov, ki so

V tem delu sva izhajali iz internega Poročila o pregledu kurikulov slovenskih fakultet (2017) avtoric M. Bohinc in V. Tašner. 
del predmetnika študentk in študentov programov, ki v Sloveniji usposabljajo večino prihodnjih učiteljic in učiteljev $\mathrm{v}$ osnovnih šolah. V Sloveniji delujejo tri pedagoške fakultete, največja in najstarejša v Ljubljani, druga v Mariboru in najmlajša v Kopru, to pa seveda niso edine vzgojno-izobraževalne institucije, ki formirajo prihodnje učiteljstvo. Pri pregledu izbranih vsebin v kurikulih naštetih fakultet sva iskali tiste programe in predmete, ki tematizirajo vprašanja nasilja in šole, otrokovih pravic in zaščite otrok $\mathrm{v}$ povezavi s šolo in družino. Zato sva $\mathrm{v}$ javno dostopnih dokumentih iskali izbrane besede, besedne zveze in koncepte, ki bi lahko bili povazani s tematizacijo nasilja v vzgojno-izobraževalnih institucijah. Uporabljena je bila metoda analize javno dostopnih dokumentov, kot so predstavitveni zborniki in učni načrti.

\section{Rezultati analize učnih načrtov po izbranih fakultetah in izbranih geslih}

\section{Pedagoška fakulteta Univerze v Ljubljani}

$\mathrm{Na}$ prvi stopnji Pedagoške fakultete Univerze v Ljubljani na smereh Razredni pouk (RP), Socialna pedagogika (SP), Dvopredmetni učitelj (DU), Likovna pedagogika (LP), Specialno rehabilitacijska pedagogika (SRP), Logopedija in surdopedagogika (LS) ter Predšolska vzgoja (PV) je $v$ predstavitvenem zborniku, kjer so predmeti opisani, mogoče najti posamične vsebine o nasilju ali zlorabah ter o otrokovih pravicah. Nekatere od navedenih vsebin so pokrite znotraj obveznega splošnega predmeta Sociologija vzgoje (na vseh omenjenih smereh), nekaj jih tematizirajo izbirni predmeti, npr. Pravice otroka in Pojmovanje in preprečevanje nasilja (DU), Zlorabe otrok, šola in vrtec (SRP), Otrok z izkušnjo nasilja $(\mathrm{PV})$. Ni pa v kurikulu posebnih predmetov o otrokovih pravicah in zaščiti otrok.

$\mathrm{Na}$ študijskih programih druge stopnje (magistrski študij) se zgodba ponovi. Obveznih predmetov oz. učnega programa, ki bi obravnaval nasilje in šolo, pravice otrok, zaščito oz. zakonodajo o pravicah otrok, ni. Izjema je obvezni splošni predmet na Edukacijskih politikah. Omenjene vsebine so sicer na voljo znotraj izbirnih predmetov na nekaterih drugostopenjskih programih. Primer izbirnega predmeta, $v$ celoti namenjenga obravnavi šole in nasilja, je interdisciplinarni seminar z naslovom Nasilje in šola za večino študijskih smeri (razen SP), ki uporablja interdisciplinarni pristop k obravnavi nasilja in šole ter ob naslovni temi pokriva še zakonodajo $s$ tega področja in otrokove pravice. Omeniti velja še predmeta Zlorabe otrok, šola in vrtec (SL) ter Sociologija vzgoje na Inkluzivni pedagogiki. 


\section{Univerza v Mariboru, Pedagoška fakulteta}

Tudi na Pedagoški fakulteti Univerze v Mariboru na prvi stopnji ni predmeta, ki bi bil v celoti namenjen obravnavi pravnega vidika otrokovih pravic, zaščite otrok, nasilja in ogroženosti otrok. Na programu Razredni pouk pri predmetu Družboslovni pedagoški praktikum obravnavajo ozaveščanje otrok o njihovih temeljnih pravicah. Na programu Predšolska vzgoja (PV) pri Predšolski pedagogiki tematizirajo položaj otrok v svetu in pri nas ter njihove pravice in njihovo uresničevanje. Pri predmetu Sociologija družine in predšolskega otroka ob drugih vsebinah obravnavajo tudi postmoderno slovensko družbo, družino in predšolskega otroka kot subjekt družinskega prava. Na dodiplomski ravni programov Likovna pedagogika, Glasbena pedagogika in Športno treniranje ni predmetov, ki bi obravnavali izbrane teme. Prav tako te teme niso omenjene v učnem načrtu.

Na drugi stopnji na programu Razredni pouk ni drugih predmetov, ki bi obravnavali teme nasilja in zaščite otrok, njihovih pravic ipd., enako velja za drugo stopnjo programov Likovna pedagogika, Glasbena pedagogika in Športno treniranje.

Na magistrskem programu PV obstaja predmet Pravni vidiki v zgodnjem otroštvu, kar je mogoče povezati z možnostjo obravnave tem nasilja, otrokovih pravic, otrok brez spremstva, itd., žal opis predmeta ni dostopen na spletni strani. Na programu Inkluzija v vzgoji in izobraževanju ( 2 . stopnja) pri predmetu Strategije dela z učenci z motnjo vida najdemo vsebino pravice otrok, učencev in dijakov z motnjo vida, ki izhajajo iz Zakona o usmerjanju otrok s posebnimi potrebami. Eden izmed ciljev programa je spoštovanje in upoštevanje otrokovih/človekovih pravic, njihove integritete in dostojanstva. Vsebine na temo temeljnih pravic otrok, otroškega prava, dela otrok je najti pri predmetu Pravni vidiki dela $v$ zgodnjem otroštvu študijskega programa Zgodnje učenje (2. stopnja).

\section{Pedagoška fakulteta Univerze na Primorskem}

Tudi na tej fakulteti na prvi stopnji ni predmetov, ki bi bili izključno namenjeni tematizaciji nasilja, pravnega vidika otrokovih pravic, zaščite. Najdemo pa na posamičnih programih vsebine, ki se dotikajo omenjenih konceptov. Npr. na Predšolski vzgoji pri predmetu Predšolska pedagogika obravnavajo pojav zagovorništva, otrokove pravice in potrebe v predšolski vzgoji, participacijo otrok, staršev in skupnosti. Pri predmetu Osnovne metode dela spredšolskimi slepimi in slabovidnimi otroki pa naj bi študent/-ka poznal/-a pravice slepih in slabovidnih otrok, ki izhajajo iz Zakona o usmerjanju otrok s posebnimi potrebami. Na smeri Razredni pouk nekaj od že omenjenih vsebine tematizirajo $\mathrm{v}$ okviru obveznega predmeta 
Didaktika družboslovja. Na Pedagogiki pa ni študijskih vsebin, ki bi pokrivala omenjene teme.

$\mathrm{Na}$ drugi stopnji na programu Inkluzivna pedagogika študentke/-i pri predmetu Metode dela sslepimi in slabovidnimi spoznajo pravice slepih in slabovidnih otrok, ki izhajajo iz Zakona o usmerjanju otrok s posebnimi potrebami. Pri predmetu Partnerstvo s starsi in okoljem v inkluziji pa se srečajo $s$ pravicami otrok in staršev. Program Zgodnje učenje pri predmetu Pravo in etika kot enega temeljnih ciljev predmeta navaja $\gg$ razvijati znanje o pravicah otrok «. Pri programih Razredni pouk in Socialna pedagogika ni predmetov ali študijskih vsebin, ki bi bile s pravnega vidika povezane z otrokovimi pravicami, zaščito, nasiljem, ogroženostjo.

Analiza izbranih dokumentov pedagoških fakultet pokaže, da vse tri fakultete znotraj svojih predmetov, obveznih in izbirnih, pokrivajo vsebine nasilja in šole, otrokovih pravic, otroškega prava, zlorabe otrok itd. Ni pa bilo v njihovih kurikulih mogoče najti samostojnega obveznega predmeta, ki bi ga bile deležne vse študentke in študenti in bi bil namenjen izključno obravnavi nasilja in šole ter pravnih dokumentov, povezanih z omenjeno problematiko.

\section{Sklep}

Vloga odgovorne osebe, ravnatelja/-ice kot pedagoške vodje, je pri nas že v Zakonu o organizaciji in financiranju vzgoje in izobraževanja (1996, 2007) natančno opredeljena, opredeljuje pa jo tudi Priročnik ob zaznavi in obravnavi medvrstniškega nasilja v vzgojno-izobraževalnih zavodih, $\mathrm{v}$ katerem je zapisano, da je vloga ravnatelja/-ice, da se vedno seznani z dogodkom in je seznanjen/-a z vsemi nadaljnjimi postopki znotraj VIZ, da po potrebi (pogosto) opravi razgovor z žrtvijo in povzročiteljem, da formalno obvešča ustrezne institucije, sodeluje z zunanjimi institucijami, če je to potrebno (policija, CSD), prav tako z javnostjo in mediji, da skrbi, da je strokovnim delavcem, če izkažejo to potrebo, omogočena strokovno podpora, ter jim zagotovi varnost, da se pogovori s starši, da skrbi, da je VIZ za otroka varovalni dejavnik, ter da sodeluje pri načrtovanju preventive (imenuje skupino). Ravnatelj/-ica kot odgovorna oseba bi morala torej poskrbeti, da se na ravni posamezne šole s pomočjo zakonskih in podzakonskih aktov ter protokola $\mathrm{z}$ navodili in priročnikom oblikuje natančen dokument politike šole $\mathrm{v}$ boju proti nasilju, ki bi bil stvar potreb posamezne šole, oblikoval bi jo tim strokovnjakov na šoli (vanj bi bili vključeni učitelji ter predstavniki učencev in sveta staršev) na podlagi analize stanja (koliko nasilja, kakšno nasilje, kje, kdaj, kako prihaja do nasilja ...) in s sodelovanjem s širšo skupnostjo (lokalna skupnost, nevladne organizacije, institucije). Dokument bi moral biti vključen v vzgojni načrt šole, kot 
del operativnega načrta vzgojnih dejavnosti, ki bi se oblikovale v skladu z načelom avtonomije šole. Šole in predvsem učiteljstvo, po najinem mnenju, potrebujejo trdno oporo (načrt), na podlagi katere bo jasno njihovo delovanje, kajti, kot je zapisano tudi v Smernicah (prav tam), si želi učiteljstvo bolje razumeti svoj položaj in dobiti dovolj strokovne pomoči, predvsem pri obvladovanju nasilja. Kot pomemben del politike spoprijema z nasiljem šole tako vidimo jasno potrebo po dodatnem izobraževanju in usposabljanju učiteljstva. Poudarek je treba usmeriti predvsem na razvoj kakovostnih programov na temo prepoznavanja, obravnavanja in preprečevanja nasilja ter na razvijanje dobrih medsebojnih odnosov in timsko delo. Poleg poznavanja problematike nasilja in soočanja z njim je namreč izjemnega pomena tudi sodelovanje med učitelji ter iskanje in nudenje pomoči znotraj šole - dobro organizirana svetovalna in strokovna pomoč. Šole se srečujejo z različnimi oblikami nasilja, delujejo v različnih okoljih in pogojih, kar vpliva na preprečevanje in obravnavanje nasilja. Kljub vsemu pa nobena posebnost šole ne sme preglasiti etične in pedagoške zaveze VIZ ter temeljnih strokovnih načel, ki učiteljem in šoli nalagajo aktivno preprečevanje nasilja ter zagotavljanje varnosti otrokom in drugim deležnikom VIZ (Lešnik Mugnaioni in Klemenčič, 20I 4: 55). Da bi od šol in učiteljstva upravičeno pričakovali zgoraj opisano ravnanje, pa moramo kot družba ustrezno financirati šolstvo in tudi dejavnosti skrbi za boj proti nasilju in družno skrbeti za pogoje, ki bodo učiteljstvu omogočali ohranjati strokovno in poklicno avtoriteto. Zdi se, da je kakovostna izobrazba učiteljstva prvi del pogoja ohranjanja avtoritete, drugi del omogočanja statusa, ki povečuje moč besede in ravnanja učiteljstva, pa zahteva primeren odnos do zahtevnega poklica učiteljic, učiteljev s strani staršev, ki pogosto prehitro vzamemo $\mathrm{v}$ bran tudi neprimerna vedenja in ravnanja naših otrok ter jim s tem dolgoročno škodimo. Podobno velja za državo, ki se mora zavedati, da nepremišljeno zmanjševanje plačila dela učiteljic in učiteljev v družbo kot celoto pošilja sporočilo o nepomembnosti, nezaslužnosti oseb, ki trenutno v Sloveniji samo v osnovnih šolah dnevno skrbijo za več kot $\mathrm{I} 86.000$ učenk in učencev ter $s$ tem dejansko tudi za njihovo in našo skupno dobrobit.

\section{Literatura in viri}

Archard, D. (2004) Children: Rights and Childhood. 2 nd ed. London; New York: Routledge.

Besag, V. E. (1989) Bullies and Victims in Schools. Buckingham: Open University Press. 
Bohinc, M. in Tašner, V. (2017) Poročilo o pregledu kurikulov slovenskih fakultet. Interno gradivo.

Bučar-Ručman, A. (2009). Kako se lahko učinkovito soočamo s šolskim nasiljem? V V. Tašner [ur.], Brez spopada. Kultur, spolov, generacij, str. 363-377. Ljubljana: Pedagoška fakulteta (Univerza v Ljubljani).

Devjak, T., \& Zorc Maver, D. (2018) Otrokove pravice in preventivno vzgojno delovanje $\mathrm{v}$ javni osnovni šoli kot odgovor na nasilje in odklonsko vedenje. Ars \& Humanitas, I2(I), str. I24-I38. Dostopno na https://doi. org/10.4312/ah.I2.I.124-138

Greene, M. B. (2005) Reducing Violence and Aggression in Schools. Trauma and Violence Abuse 6(3), str. 236-253.

Kodelja, Z. (1995) Laična šola: pro et contra. Ljubljana: Mladinska knjiga

Kodelja, Z. (2015) Participativne pravice otrok: pravica do glasu, svobode misli, vere, združevanja. V: Alenka Šelih in Katja Filipčič [ur.], Otrokove pravice $v$ Sloveniji: sedanje stanje in izzivi za prihodnost, str. 99-I15. Ljubljana: Slovenska akademija znanosti in umetnosti.

Korošec, D. (2009) Kazenska odgovornost učitelja v zvezi z nasiljem v šoli. Pravni letopis I. str. 40I-409.

Lines, D. (2008) The Bullies: Understanding Bullies and Bullying. London: Kingsley.

Lešnik Mugnaioni, D. in I. Klemenčič (20I4) Smernice za obravnavo vrstniškega nasilja v šoli. Vodenje v vzgoji in izobraževanju I, str. 33-57.

Nussdorfer, V. (2014) Spremna beseda. V: Irena Jager Agius [ur.], Otrokove pravice $v$ Slovenije. Od normativnih standardov do učinkovitega varstva (XIII-XVII). Ljubljana. Fakulteta za družbene vede, Založba FDV..

Olweus, D. (1993) Bullying at School: What we Know and What we Can Do. Malden, MA: Blackwell Publishing.

Pravilnik o obravnavi nasilja $v$ družini za vzgojno-izobraževalne zavode (2008). Pridobljeno 26. 6. 2019 s https://www.uradni-list.si/ glasilo-uradni-list-rs/vsebina/95147

Protokol ob zaznavi in za obravnavo medvrstniškega nasilja v vzgojnoizobraževalnih zavodih (2016) Pridobljeno I. 7. 2019 s http://www.os-mojstrana.si/userfiles/images/Datoteke/ Protokol\%2oob\%2ozaznavi\%2oin\%2o za\%2oobravnavo\%2omedvrstnikega\%2onasilja\%2ov\%2oVIZ.pdf

Rigby, K. (2008) Children and Bullying: How Parents and Educators Can Reduce Bullying at School. Oxford: Blackwell.

Šelih, A. in Filipčič, K. [ur.] (2015) Otrokove pravice v Sloveniji: sedanje stanje in izzivi za prihodnost. Ljubljana: Slovenska akademija znanosti in umetnosti. 
Tašner, V. [ur.] (2009) Brez spopada. Kultur, spolov, generacij. Ljubljana: Pedagoška fakulteta (Univerza v Ljubljani).

Ustava RS (199I) Pridobljeno 2. 7. $2019 \mathrm{~s} \mathrm{https://zakonodaja.com/ustava/urs/}$ ii-poglavje-clovekove-pravice-in-temeljne-svoboscine

Zakon o organizaciji in financiranju v vzgoji in izobraževanju (2007)

Pridobljeno I. 6. 2019 s https://www.uradni-list.si/glasilo-uradni-list-rs/ vsebina/2007-0I-07I8?sop=2007-0I-

Zakon o Osnovni šoli (2006) Pridobljeno 2. 6. 2019 s https://www.uradni-list. si/glasilo-uradni-list-rs/vsebina/2006-oI-3535?sop=2006-0I-3535

Zakon o preprečevanju nasilja v družini (2008) Pridobljeno 26. 6. $2019 \mathrm{~s}$ http://www.pisrs.si/ Pis.web/pregledPredpisa?id=ZAKO 5084

DOI: https://www.doi.org/I0.32320/158I-6044.30(I-2)137-150 